\title{
Patient with coronary artery disease and hypertension
}

\author{
Dragan Lovic ${ }^{1}$, Dragan Djordjevic ${ }^{2}$, Ivan Tasic², Branko Lovic ${ }^{1}$, Vesna Stojanov³, \\ Branko Jakovljevic ${ }^{3}$, Milan Nedeljkovic ${ }^{3}$ \\ ${ }^{1}$ Clinic for internal disease Intermedica, Hypertension Center, Nis, Serbia, ${ }^{2}$ Institute Niska Banja, Medical School \\ University Nis, Serbia, ${ }^{3}$ Clinical Center Serbia, Cardiology Clinic, Medical School University Belgrade, Serbia
}

Abstract

Background: Cardiovascular mortality is and will be number one cause of death in years to come. Many risk factors such as hypertension, diabetes mellitus, dyslipidemias and obesity are related with increase risk of cardiovascular diseases.

Case Report: We present the case of a patient with a significant medical history of hypertension, dyslipidemia, type 2 diabetes, obesity who presented to the emergency department with atypical chest pain. Patient had uncontrolled blood pressure and high level of cholesterol. He was smoker, obese and physically inactive. He underwent a cardiac catheterization that showed a stenosis on right coronary artery originating near the anterior left coronary artery sinus and coursing between. The patient was discharged home on medical management with beta blocker therapy, ACEi, statin and antidiabetic therapy, and was instructed to restrict his physical activity and reduce body weigh. Conclusion: Treatment of patients with coronary artery disease is demanding control of the blood pressure, cholesterol and blood glucose. Many Guidelines try to find optimal treatment and goals in treatment in case to improve quality of life and complications. Any way symptomatic patients with coronary artery disease have 3 treatment options: medical management, coronary angioplasty and stent deployment, or surgical correction.

Kew words arterial hypertension, coronary heart disease, treatment

\section{Introduction}

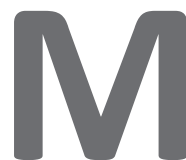

ost variations of cardiovascular diseases are still number one cause of dead in a modern world. Investigators estimate that in a near future we will have slowly decrease but still leading cause and highest mortality will be related to cardiovascular disease.

However, hypertension is on the top of list of separate diseases with very high mortality anywhere in the world. Many epidemiological studies demonstrated that other factors such as diabetes mellitus, dyslipidemias, obesity and unhealthy way of leaving increase in a past decade.

\section{Case report}

A 65-year-old male with a significant medical history of hypertension, hyperlipidemia, type 2 diabetes, obesity, presented to the emergency department with atypical cardiac chest pain. He complained of intermittent chest discomfort that had persisted for 2 months. He described the pain as 5 of 10 in severity, substernal, lasting less than 1 minute, nonradiating, resolving spontaneously but becoming acutely worse overnight with minimal exertion. He had never taken sublingual nitroglycerin to relieve his pain, and his electrocardiogram (ECG) on presentation showed normal sinus rhythm with ST and T wave abnormalities potentially indicating anterior and inferior ischemia seen in III, aVF, and V1-V3 (Figure 1). His 2D echocardiogram 2 months prior to admission had shown a normal ejection fraction (55\%) with reduce diastolic function grade II. A bedside echocardiogram showed normal ejection fraction with severe left ventricular hypertrophy.

He was taking medicaments for blood pressure, diabetes and dyslipidemia but on his examination he had elevated blood pressure 155/95 $\mathrm{mmHg}$, with heart rate 65 per minute. Blood glucose was $118 \mathrm{mg} / \mathrm{dl}$, cholesterol $151 \mathrm{mg} / \mathrm{dl}, \mathrm{HbA} 1 \mathrm{C}$ 6,7\% , LDL 68 mg/dl, triglycerides 101 $\mathrm{mg} / \mathrm{dl}$, urea $39 \mathrm{mg} / \mathrm{dl}$ and creatinine $1,0 \mathrm{mg} / \mathrm{dl}$.

He was admitted to cardiology for unstable angina and underwent a cardiac catheterization that showed an anomaly of RCA. Patient then received medical therapy and was discharged home on a stable condition.

\section{Discussion}

Epidemiological studies have established a strong association between hypertension and coronary artery disease (CAD). Hypertension is a major independent risk factor for the development of CAD, stroke, and renal failure. The optimal choice of antihypertensive agents remains controversial, and there are only partial answers to important questions in the treatment of hypertension for the prevention and management of ischemic heart disease (IHD). 


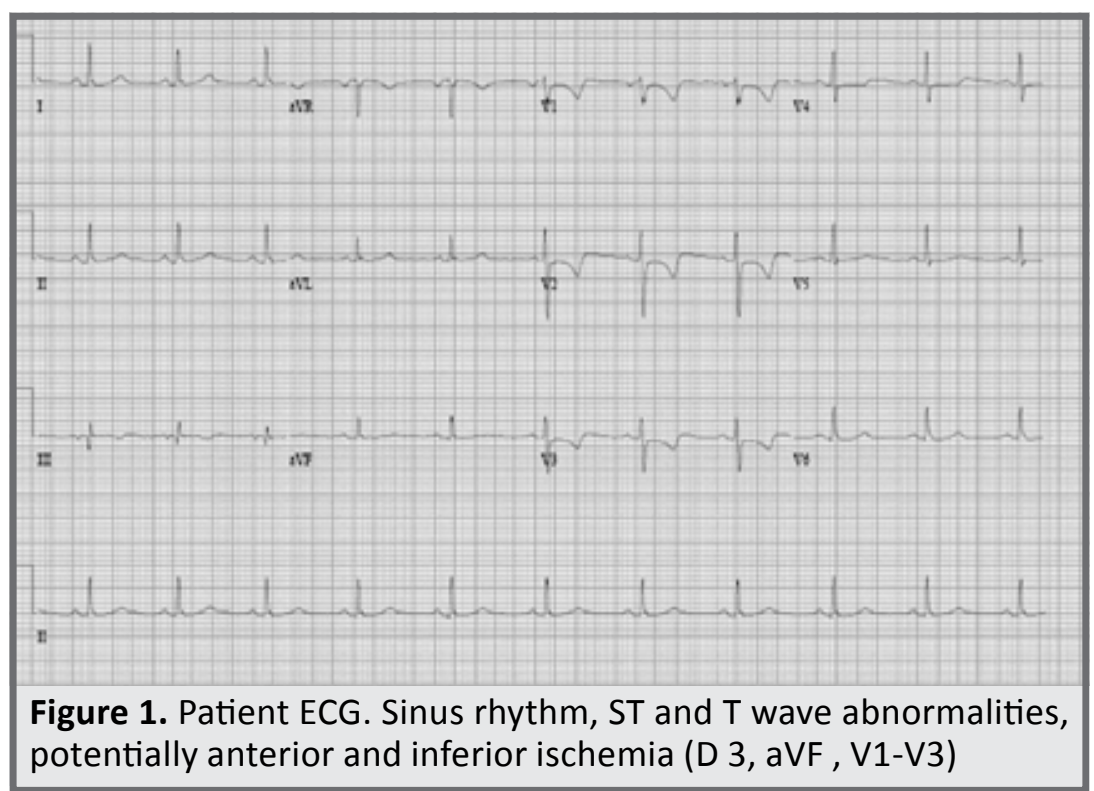

The prevalence of hypertension is thus directly proportional to the age of the population, with more than half of people $>65$ years of age having a high BP. The Framingham Heart Study has estimated the remaining lifetime risk of developing hypertension at $\approx 90 \%$ for men and women not yet hypertensive by middle age. ${ }^{1}$ In addition; there is a change with age in the relative importance of SBP and DBP as risk indicators. Before 50 years of age, DBP is the major predictor of IHD risk, whereas after 60 years of age, SBP is more important. ${ }^{5}$ It is important to note that, in this population $\geq 60$ years of age, DBP becomes inversely related to CAD risk and pulse pressure becomes the strongest predictor for CAD.

Randomized trials have shown that BP lowering in patients with hypertension produces rapid reductions in cardiovascular risk that are highly consistent with data from observational studies ${ }^{2,3}$. For example, a 10$\mathrm{mm} \mathrm{Hg}$ lower usual SBP is associated with a $50 \%$ to $60 \%$ lower risk of stroke death and $a \approx 40 \%$ to $50 \%$ lower risk of death resulting from CAD

Several studies (Heart Outcomes Prevention Evaluation [HOPE], Survival and Ventricular Enlargement [SAVE], and European Trial on Reduction of Cardiac Events With Perindopril in Stable Coronary Artery Disease [EUROPA]) have shown a beneficial effect of angiotensin-converting enzyme (ACE) inhibitors on CVD outcomes in individuals. ${ }^{4,5,6}$

In the Action to Control Cardiovascular Risk in Diabetes (ACCORD) trial, with a mean follow-up of 4.7 years, a target BP of $<120$ compared with $<140 \mathrm{~mm} \mathrm{Hg}$ was not associated with a reduced risk of a composite of CVD events (heart attack, a stroke, or a cardiovascular death). ${ }^{7,8}$

Meta-analyses of antihypertensive trials have demonstrated that BP lowering is more important than the particular drug class used in the primary prevention of the complications of hypertension. ${ }^{9}$ Combination antihypertensive drug therapy is typically needed to achieve and to sustain effective long-term BP control. ${ }^{10}$

The overall goal of therapy is to reduce excess morbidity and unnecessary deaths. In the case of hypertension, dyslipidemia, and diabetes mellitus have been established therapeutic targets. A commonly cited target for
$B P$ is $<140 / 90 \mathrm{~mm} \mathrm{Hg}$ in general and $<130 / 80 \mathrm{~mm} \mathrm{Hg}$ in some individuals with diabetes mellitus or CKD. The first AHA scientific statement from 2015 on the treatment of hypertension in the prevention and management of IHD also recommended a goal of $<130 / 80 \mathrm{~mm} \mathrm{Hg}$ in individuals with established CAD, with CAD equivalents, or with a Framingham Risk Score of $\geq 10 \%{ }^{11,12,13}$

New AHA guidelines, published in November 2017, suggest blood pressure $<130 / 80 \mathrm{mmHg}$ as a target values in control of blood pressure in patients with CAD. To achieve these targets in adults with DM and hypertension, as useful and effective group of drugs are recommended beta blockers, diuretics, ACE inhibitors, ARBs, and CCBs. ${ }^{14}$

Except hypertension, it should be emphasize effect of dyslipidemia, diabetes mellitus, cigarette smoking, obesity, and chronic kidney disease (CKD) as independent determinants of CVD risk. As indicated previously, hypertension represents an independent risk factor for CVD, and evidence indicates that the concomitant presence of other recognized cardiovascular risk factors results in a multiplicative increase in risk for cardiovascular events. Some current guidelines call for more aggressive BP management in the presence of other cardiovascular risk factors, and BP reduction without attention to other risk factors is inadequate to reduce cardiovascular risk. ${ }^{15}$

It should to emphasize that there is general consensus that smoking increases the risk of cardiovascular events. Many studies have shown a correlation between smoking and death. Life expectancy is reduced by 13.2 years in male smokers compared with nonsmokers, and this trend is stronger in female smokers, with a 14.5year decrease in life expectancy. ${ }^{15}$

The prevalence of obesity, defined as a body mass index $\geq 30 \mathrm{~kg} / \mathrm{m}^{2}$, has increased in recent years, with $\approx 30 \%$ of the adult falling into this category. The positive relationship between obesity and BP is well documented. Obese adults are $\approx 3$ times more likely to be hypertensive compared with non obese adults, and increased adiposity may explain $>60 \%$ of hypertension in adults. ${ }^{15}$

The management of dyslipidemia was the subject of a recent $\mathrm{ACC} / \mathrm{AHA}$ guideline. 
The guideline advocates the use of a 10-year risk calculator determine the appropriate intensity of statin therapy to reduce CVD risk in those most likely to benefit. Those patients with CVD and age $\leq 75$ years, with LDL cholesterol $\geq 190 \mathrm{mg} / \mathrm{dL}$, or with a 10 -year CVD risk $\geq 7.5 \%$ should receive high intensity statin therapy (eg, atorvastatin $40-80 \mathrm{mg} / \mathrm{d}$ or rosuvastatin $20-40 \mathrm{mg} / \mathrm{d}$ to reduce LDL cholesterol by approximately $\geq 50 \%$ ). Those with CVD who are $>75$ years of age or those with diabetes mellitus but with a 10 -year risk of $<7.5 \%$ should receive moderateintensity statin therapy such as simvastatin 20 to 40 $\mathrm{mg} / \mathrm{d}$, atorvastatin 10 to $20 \mathrm{mg} / \mathrm{d}$, or rosuvastatin 5 to 10 $\mathrm{mg} / \mathrm{d}$ to decrease LDL cholesterol by $30 \%$ to $50 \%$. $^{16,17}$

Patients with type 2 diabetes mellitus is defined as a fasting plasma glucose $\geq 126 \mathrm{mg} / \mathrm{dL}$, a 2-hour oral glucose tolerance test value $\geq 200 \mathrm{mg} / \mathrm{dL}$, hemoglobin A1C $\geq 6.5 \%$, or random plasma glucose $\geq 200 \mathrm{mg} / \mathrm{dL}$ in a patient with classic symptoms of hyperglycemia. Type 2 diabetes mellitus is a strong and independent risk factor for coronary heart disease. So strong is this association that a diagnosis of diabetes mellitus could be considered a coronary heart disease risk equivalent, although this is controversial. Hypertensive patients with type 2 diabetes mellitus are also at increased risk for diabetes mellitus-specific complications, including retinopathy and nephropathy

\section{Conclusion}

This case illustrates an example of an patient with history of hypertension and coronary diseases in a elderly patient presenting with chest pain. The preferred treatment for these patients is conservative medical therapy with good control of blood pressure and other factors.

\section{References}

1. Rosendorff C, Black HR, Cannon CP, et al. Treatment of hypertension in the prevention and management of ischemic heart disease: a scientific statement from the American Heart Association Council for High Blood Pressure Research and the Councils on Clinical Cardiology and Epidemiology and Prevention. Circulation. 2007;115:2761-2788.

2. Lipton MJ, Barry WH, Obrez I, et al. Isolated single coronary artery: diagnosis, angiographic classification, and clinical significance. Radiology. 1999 Jan;130:39-47.

3. Chobanian AV, Bakris GI, Black HR, and the National High Blood Pressure Education Program Coordinating Committee. Seventh report of the Joint National Committee on Prevention, Detection, Evaluation, and Treatment of High Blood Pressure. Hypertension. 2003;42:1206 -1252.
4. Yusuf S, Sleight P, Pogue J,et al. Effects of an angiotensin-converting-enzyme inhibitor, ramipril, on cardiovascular events in highrisk patients: the Heart Outcomes Prevention Evaluation Study Investigators. N Engl J Med. 2000;342:145-153.

5. Pfeffer MA, Braunwald E, Moye LA, et al: SAVE Investigators. Effect of captopril on mortality and morbidity in patients with left ventricular dysfunction after myocardial infarction: results of the Survival and Ventricular Enlargement trial: the SAVE Investigators. N Engl J Med. 1992; 327: 669-677.

6. Fox KM; EURopean trial On reduction of cardiac events with Perindopril in stable coronary Artery disease Investigators. Efficacy of perindopril in reduction of cardiovascular events among patients with stable coronary artery disease: randomised, doubleblind, placebo-controlled, multicentre trial (the EUROPA study). Lancet. 2003;362:782-788.

7. Julius S, Nesbitt SD, Egan BM, et al; Trial of Preventing Hypertension (TROPHY) Study Investigators. Feasibility of treating prehypertension with an angiotensin-receptor blocker. N Engl J Med. 2006;354:1685-1697.

8. ACCORD Study Group; Cushman WC, Evans GW, Byington RP, et al. Effects of intensive blood-pressure control in type 2 diabetes mellitus. N Engl J Med. 2010:362:1575-1585.

9. Mancia G, Fagard R, Narkiewicz K, et al. 2013 ESH/ESC guidelines for the management of arterial hypertension: the Task Force for the Management of Arterial Hypertension of the European Society of Hypertension (ESH) and of the European Society of Cardiology (ESC). Eur Heart J 2013;34:2159-219.

10. Thomopoulos C, Parati G, Zanchetti A. Effects of blood-pressurelowering treatment on outcome incidence. 12. Effects in individuals with high-normal and normal blood pressure: overview and meta analyses of randomized trials. J Hypertens. 2017 Nov;35:2150-2160

11. Thomopoulos C, Parati G, Zanchetti A. Effects of blood pressurelowering on outcome incidence in hypertension: 5. Head-tohead comparisons of various classes of antihypertensive drugs - overview and meta-analyses. J Hypertens 2015;33(7):1321-41

12. Ettehad D, Emdin CA, Kiran A, et al. Blood pressure lowering for prevention of cardiovascular disease and death: a systematic review and meta-analysis. Lancet 2016;387:957-967.

13. Emdin CA, Rahimi $\mathrm{K}$, Neal B, et al. Blood pressure lowering in type 2 diabetes: a systematic review and meta-analysis. JAMA 2015; 313:603-15.

14. Paul K. Whelton, Robert M, et al. 2017 ACC/AHA/ AAPA/ABC/ ACPM/AGS/APhA/ASH/ASPC/NMA/PCNA Guideline for the Prevention, Detection, Evaluation, and Management of High Blood Pressure in Adults. Journal of the American College of Cardiology; https://doi.org/10.1016/j.jacc.2017.11.006

15. Kotseva K, Wood D, De Bacquer D, Lovic D, Vulic D; on behalf of the EUROASPIRE Investigators. EUROASPIRE IV: A European Society of Cardiology survey on the lifestyle, risk factor and therapeutic management of coronary patients from 24 European countries.Eur J Prev Cardiol. 2016 Apr;23:636-48

16. Yusuf S, Bosch J, Dagenais G, et al. HOPE-3 Investigators. Cholesterol Lowering in Intermediate-Risk Persons without Cardiovascular Disease. N Engl J Med 2016;374:2021-31.

17. Authors/Task Force Members: Catapano AL, Graham I, De Backer G,et al. 2016 ESC/EAS Guidelines for the Management of Dyslipidaemias. Eur Heart J 2016;37:2999-3058. 


\section{Sažetak}

\section{Pacijent sa koronarnom bolešću i hipertenzijom}

Dragan Lović, Dragan Đorđević2, Ivan Tasić2, Branko Lović1, Vesna Stojanov 3 , Branko Jakovljević3, Milan Nedeljković ${ }^{3}$

${ }^{1}$ Klinika za internu medicinu Intermedica, Centar za hipertenziju, Niš, Srbija, ${ }^{2}$ Institut za rehabilitaciju Niška banja, Medicinski fakultet, Univerzitet u Nišu, Niš, Srbija ${ }^{3}$ Klinika za kardiologiju, Klinički centar Srbija, Medicinski fakultet, Univerzitet u Beogradu, Beograd, Srbija Smrtnost od kardiovaskularnih oboljenja, kao masovna nezarazna oboljenja, biće i u narednim godinama vodeći uzrok smrti. Mnogi faktori rizika kao što su hipertenzija, dijabetes melitus, dislipidemije i gojaznost povećavaju rizik za kardiovaskularnu smrtnost

Prikaz slučaja: Pacijent sa dugogodišnjom istorijom hipertenzije, i povećanim masnoćama u krvi, tip 2 dijabetesom, gojazan javlja se na pregled sa atipičnim bolom u grudima. Pacijent ima nekontrolisan krvni pritisak i visoke vrednosti holesterola u krvi, pušač, gojazan i fizički neaktivan. Podvrgnut je kateterizaciji koronarnih arterija koja je pokazala stenozu desne koronarne arterije blizu račve sa levom koronarnom arterijom. Pacijent je nakon detaljnih analiza i pregleda otpušten na kućno lečenje uz medikamentoznu terapiju beta blokator, ACl inhibitor, statin i terapija za regulaciju šećera u krvi. Savetovana mu promena načina života i primena nefarmakoloških mera.

Zaključak: Lečenje pacijenata sa koronarnom arterijskom bolešću zahteva adekvatnu kontrolu krvnog pritiska, holesterola i šećera u krvi. Mnogi vodiči relevantnih Udruženja pokušavaju u proteklim godinama da na osnovu rezultata kliničkih studija i dostupnih dokaza, preporuče optimalne ciljeve u lečenju, a sa ciljem da poprave kvalitet života i spreče komplikacije. U svakom slučaju, pacijenti sa koranarnom bolešću imaju tri opcije u lečenju: medikamentozna terapija, koronarna angioplastika i ugradnja stenta ili hirurška korekcija (by pass).

Ključne reči: arterijska hipertenzija, koronarna bolest, tretman 